\title{
Antibiotics as a Stressing Factor Triggering the Harboring of Helicobacter pylori J99 within Candida albicans ATCC10231
}

\author{
Kimberly Sánchez-Alonzo ${ }^{1}{ }^{\mathbb{D}}$, Libnny Belmar ${ }^{1}$, Cristian Parra-Sepúlveda $^{1}{ }^{\mathbb{D}}$, Humberto Bernasconi ${ }^{2}$, \\ Víctor L. Campos ${ }^{3}$, Carlos T. Smith ${ }^{1}$ (D), Katia Sáez ${ }^{4}$ and Apolinaria García-Cancino ${ }^{1, *(D)}$ \\ 1 Laboratory of Bacterial Pathogenicity, Department of Microbiology, Faculty of Biological Sciences, \\ Universidad de Concepción, Concepción 4070386, Chile; kimsanchez@udec.cl (K.S.-A.); \\ lbelmar@udec.cl (L.B.); cparras@udec.cl (C.P.-S.); csmith@udec.cl (C.T.S.) \\ 2 Laboratorio Pasteur, Concepción 4030000, Chile; hbernasconi@lpasteur.cl \\ 3 Laboratory of Environmental Microbiology, Department of Microbiology, Faculty of Biological Sciences, \\ Universidad de Concepción, Concepción 4070386, Chile; vcamapos@udec.cl \\ 4 Department of Statistics, Faculty of Physical and Mathematical Sciences, Universidad de Concepción, \\ Concepción 4070386, Chile; ksaez@udec.cl \\ * Correspondence: apgarcia@udec.cl; Tel.: +56-41-2204144; Fax: +56-41-2245975
}

\section{check for}

updates

Citation: Sánchez-Alonzo, K.; Belmar, L.; Parra-Sepúlveda, C.; Bernasconi, H.; Campos, V.L.; Smith, C.T.; Sáez, K.; García-Cancino, A. Antibiotics as a Stressing Factor Triggering the Harboring of Helicobacter pylori $\mathrm{J} 99$ within Candida albicans ATCC10231. Pathogens 2021, 10, 382. https://doi.org/10.3390/ pathogens 10030382

Academic Editor: Takeaki Wajima

Received: 5 March 2021

Accepted: 16 March 2021

Published: 23 March 2021

Publisher's Note: MDPI stays neutral with regard to jurisdictional claims in published maps and institutional affiliations.

Copyright: (c) 2021 by the authors. Licensee MDPI, Basel, Switzerland. This article is an open access article distributed under the terms and conditions of the Creative Commons Attribution (CC BY) license (https:/ / creativecommons.org/licenses/by/ $4.0 /)$.

\begin{abstract}
First-line treatment for Helicobacter pylori includes amoxicillin and clarithromycin or metronidazole plus a proton pump inhibitor. Treatment failure is associated with antibiotic resistance and possibly also with internalization of $H$. pylori into eukaryotic cells, such as yeasts. Factors triggering the entry of $H$. pylori into yeast are poorly understood. Therefore, the aim of this study was to evaluate whether clarithromycin or amoxicillin trigger the entry of $H$. pylori into C. albicans cells. Methods: H. pylori J99 and C. albicans ATCC 10231 were co-cultured in the presence of subinhibitory concentrations of amoxicillin and clarithromycin as stressors. Bacterial-bearing yeasts were observed by fresh examination. The viability of bacteria within yeasts was evaluated, confirming the entry of bacteria into Candida, amplifying, by PCR, the H. pylori $16 S$ rRNA gene in total yeast DNA. Results: Amoxicillin significantly increased the entry of $H$. pylori into C. albicans compared to the control. Conclusion: the internalization of $H$. pylori into C. albicans in the presence of antibiotics is dependent on the type of antibiotic used, and it suggests that a therapy including amoxicillin may stimulate the entry of the bacterium into Candida, thus negatively affecting the success of the treatment.
\end{abstract}

Keywords: Helicobacter pylori; Candida albicans; antibiotic; internalization; eradication failure

\section{Introduction}

Helicobacter pylori is a bacterium that colonizes the human stomach, causing pathologies such as gastritis, peptic ulcer and malignancies including gastric adenocarcinoma and B cell lymphomas of the gastric mucosa-associated lymphoid tissue [1], which is why it is considered a type 1 carcinogen by the International Agency for Research on Cancer [2]. The prevalence of $H$. pylori has varied within the last twenty years in different regions of the world, being higher in Africa and Asia. Its prevalence of infection in South America is led by Chile (74.6\%), Ecuador (72.2\%) and Brazil (71.2\%) [3]. Taking into consideration that H. pylori has been associated with the development of cancer, the study of this pathogen's antibiotic resistance and its prevalence has been relevant since its discovery. Some of the aims of these studies have been the search for tools to elucidate the transmission mechanisms of $H$. pylori infection and to create treatment schemes using antibiotics, which will allow js to eradicate the infection by this pathogen $[1,4-8]$.

Over the last twenty years, the treatment recommended to eradicate this bacterium has been the standard triple therapy, including an inhibitor of the proton pump or ranitidinebismuth-citrate associated with clarithromycin (CLT) and amoxicillin (AMX) or metronidazole (MTZ). Nevertheless, the increasing resistance of H. pylori to the antibiotics used, 
mainly CLT, has reduced the success of this treatment scheme. Therefore, second-line therapies such as the sequential or quadruple ones have been used. Even more, thirdor fourth-line therapies have been used when the first two have failed [9-12]. The main challenge in the treatment of $H$. pylori is its resistance to the treatment with antibiotics, which is alarmingly high in certain geographical regions for antibiotics such as CLT, MTZ and levofloxacin, and is attributed to their abuse $[8,13,14]$. Therefore, $H$. pylori strains resistant to CLT have been defined as a high priority by the WHO to search for and develop new drugs to help in their treatment [15].

Although treatments have lost their effectiveness, mainly due to the emergence of CLTresistant strains, there are other factors that also contribute to their failure. In this respect, it has been shown that certain drugs used to eradicate this bacterium, such as AMX, CLT or MTZ, might act as stressing factors for H. pylori, triggering morphological and physiological adaptations, such as the coccoid morphology $[16,17]$. The coccoid morphology may be clinically associated with resistance, transmission of the infection and its recurrence after antibiotic treatment [18]. Moreover, within the last years, sufficient evidence has been gathered indicating that $H$. pylori may in vivo and in vitro be harbored within several eukaryotic cells, such as human gastric epithelial cells, immune cells, amoebas and Candida yeasts. These findings suggest that this bacterium may protect itself from challenges that threaten its viability, such as changes in environmental $\mathrm{pH}$ or eluding antibiotic treatments to eradicate it $[7,19-22]$

Although not much evidence exists on the factors promoting the entry of $H$. pylori into yeast cells [23], it has been demonstrated that the presence of antibiotics MTZ and CLT in the culture medium significantly increased the entry of $H$. pylori [7]. This supports the results of Lai and coworkers [23] co-culturing GES-1 cells and H. pylori in the presence of AMX, furazolidone, CLT, MTZ and levofloxacin, and their obtained results were similar to those of previous authors. Thus, they concluded that $H$. pylori protects itself from antibiotics harboring within other cells, evading the eradication of $H$. pylori infection.

Recently, our research group demonstrated that acidic $\mathrm{pH}$, as a stress factor, induces the entry of $H$. pylori into Candida albicans cells, where the bacterium may find a shelter against unfavorable $\mathrm{pH}$ conditions within the yeast cells [24], a yeast that colonizes the gastrointestinal tract of nearly $40 \%$ of healthy humans $[25,26]$. Similarly, certain antibiotics may also trigger the harboring of $H$. pylori within C. albicans; therefore, the H. pylori and C. albicans interaction may be an example of the bacteria-yeast relationship, which may cause the failure of anti-H. pylori treatments. Thus, the aim of the present work was to evaluate if the antibiotics used in the triple therapy against $H$. pylori might stimulate, acting as stressing agents, the harboring of $H$. pylori cells within the yeast $C$. albicans.

\section{Results}

2.1. Growth Curves of H. pylori $J 99$ (ATCC 700824) Strain and C. albicans ATCC10231 Strain

The growth curves of $H$. pylori $\mathrm{J} 99$ and C. albicans ATCC10231 strains cultured in Brucella broth supplemented with 10\% fetal calf serum (BB-FCS) under aerobic conditions are shown in Figure 1. Based on these results, the co-cultures of these two microorganisms for the following experiments were prepared using $20 \mathrm{~h}$ pure cultures of H. pylori $\mathrm{J} 99$ and $10 \mathrm{~h}$ pure cultures of $C$. albicans ATCC 10231 strains. 
A)

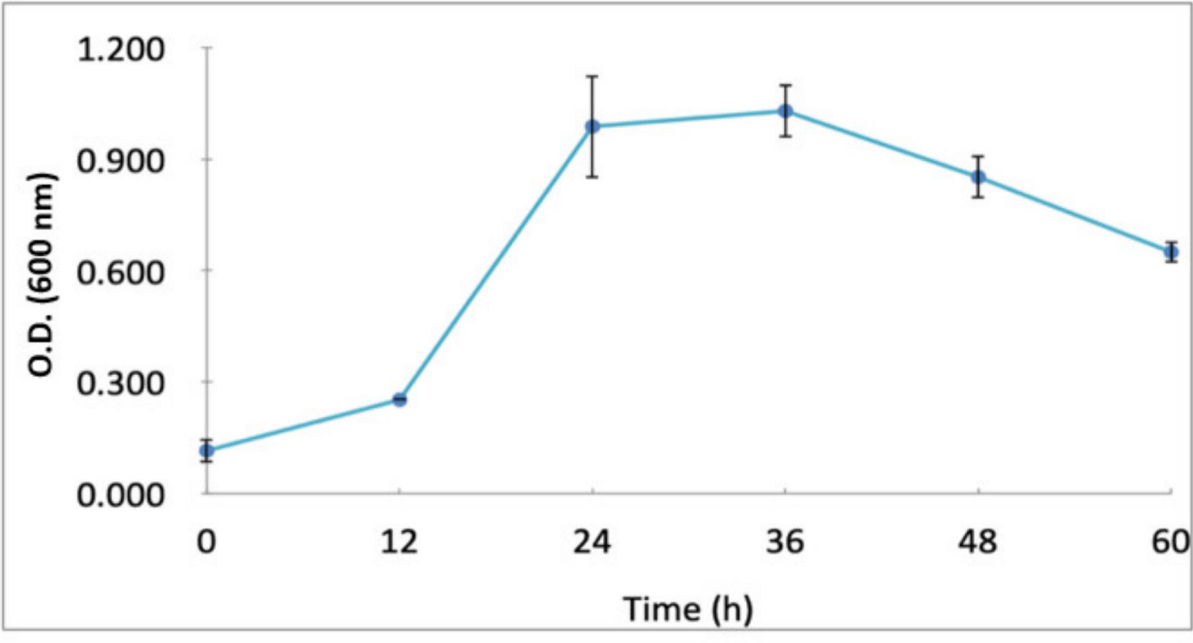

B)

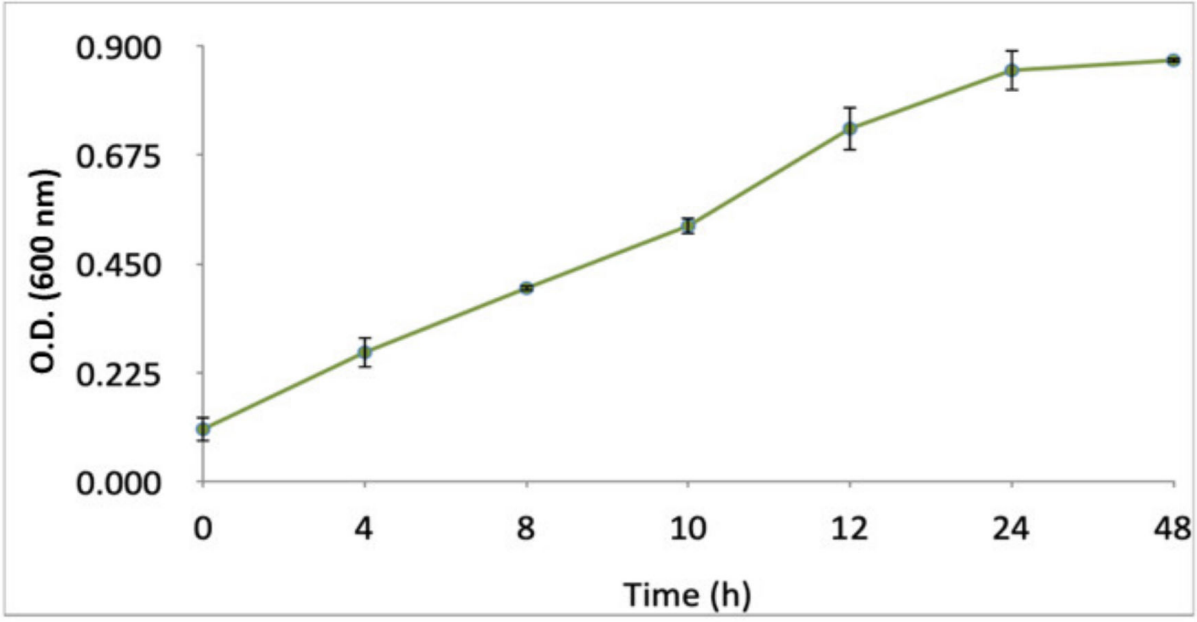

Figure 1. Growth curves of H. pylori J99 (A) and C. albicans ATCC 10231 (B) cultured in Brucella broth fetal calf serum under microaerobic conditions. O.D.: optical density. Mean of triplicates.

2.2. H. pylori J99-C. albicans ATCC 10231 Co-Culture Assay in the Presence of a Subinhibitory Concentration (1/4 Minimal Inhibitory Concentration MIC $=0.0075 \mu \mathrm{g} \mathrm{mL}{ }^{-1}$ ) of AMX or CLT

Wet mountings, observed under an optical microscope, showed the presence of bacteria-like bodies (BLBs) within yeasts and hyphae of C. albicans. Actively moving BLBs were observed within almost all hyphae observed (Figure 2). In the control co-culture, that is, in the absence of antibiotics, $25 \%$ and $34 \%$ of hyphae showed the presence of intracellular BLBs at $3 \mathrm{~h}$ and $12 \mathrm{~h}$, respectively. The latter percentage remained unchanged until the end of the $48 \mathrm{~h}$ of culture. The co-culture in the presence of 1/4 MIC CLT showed percentages of yeast cells containing BLBs not significantly different from those of the control co-culture (21\% and $33 \%$ at times $3 \mathrm{~h}$ and $12 \mathrm{~h}$, respectively) (Figure 3 ). On the contrary, in the presence of $1 / 4$ MIC AMX, the results were significantly different from those of the control and CLT containing co-cultures, showing the presence of yeasts containing BLBs from time zero on, and the percentages grew rapidly to reach $80 \%$ after $48 \mathrm{~h}$ of incubation (Figure 3). 

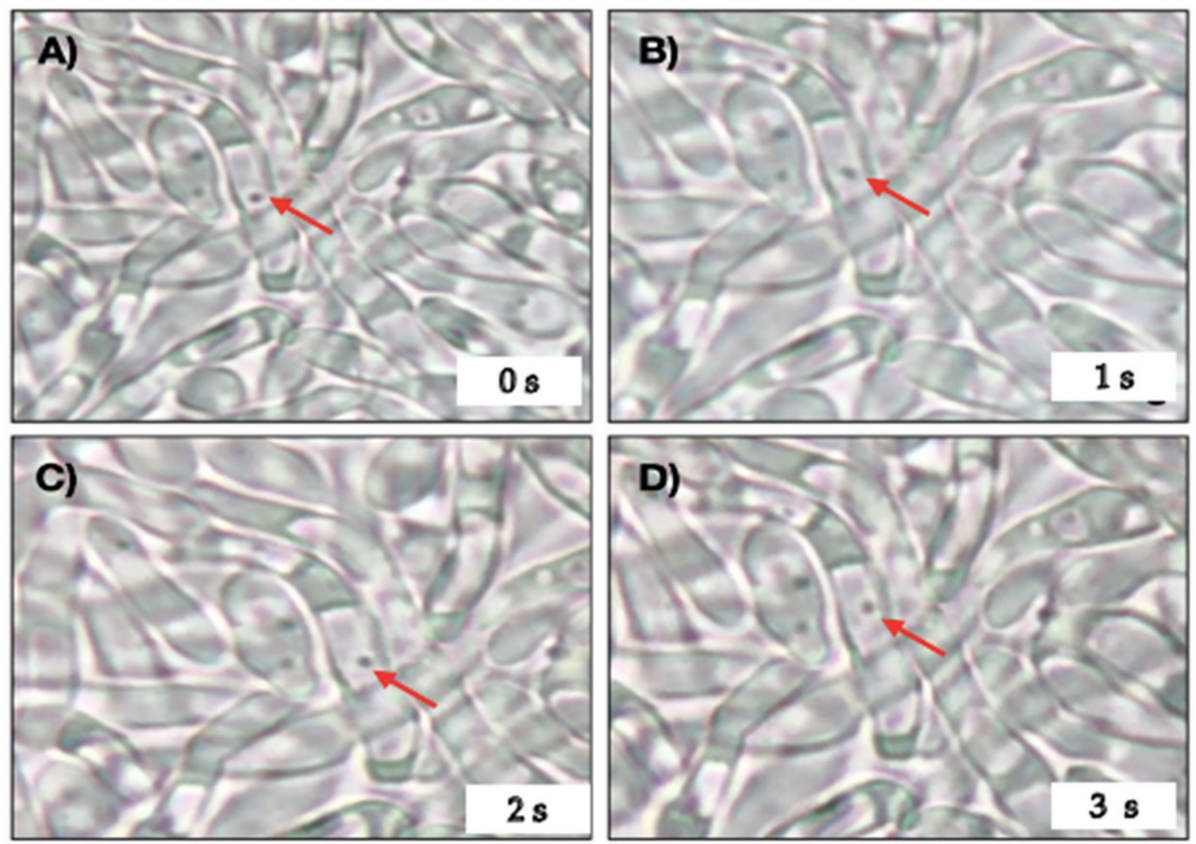

Figure 2. Optical microscopy of wet mounts of a $24 \mathrm{~h}$ H. pylori J99-C. albicans ATCC 10231 co-culture in the presence of a subinhibitory concentration of AMX. Red arrows indicate the movement of a bacteria-like body (BLB) within a yeast cell in micrographs taken at intervals of $1 \mathrm{~s}$. AMX: amoxicillin. (A) Shows the initial position of a BLB at time zero (0 s) and (B-D), show in the change in position of the BLB at $1 \mathrm{~s}$ intervals. Video S1 Movement of BLBs within vacuoles.

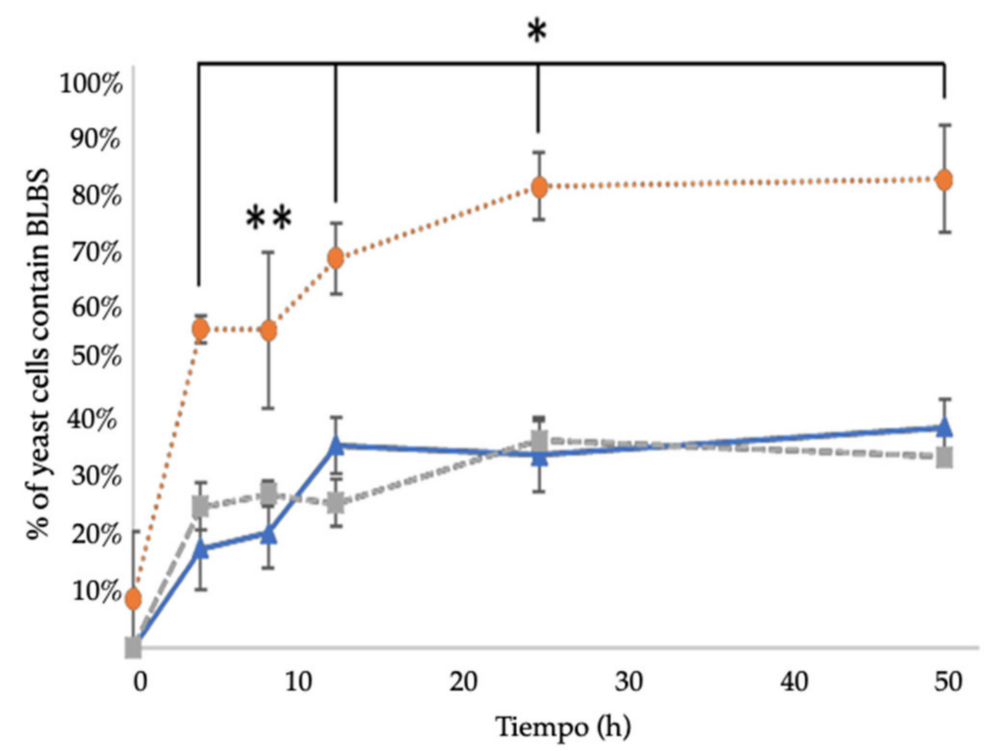

Figure 3. Percentage of $C$. albicans yeast cells containing BLBs, putatively $H$. pylori, evaluated by optical microscopy after co-culturing C. albicans ATCC 10231 and H. pylori J99. Co-culture in the absence of antibiotic (control) $(\Delta)$, co-culture in the presence of 1/4 MIC CLT ( $\square$ ), co-culture in the presence of $1 / 4$ MIC AMX ( $\bullet$. Mean of duplicates. ${ }^{*} p<0.05,{ }^{* *} p<0.1$ with respect to control. BLBs: bacteria-like body MIC: minimal inhibitory concentration, CLT: clarithromycin, AMX: amoxicillin.

\subsection{Cell Viability Assay}

Observations of co-cultures using fluorescence microscopy after staining with the LIVE/DEAD BacLight Bacterial Viability kit showed that both the yeast cells and the BLBs they contained were viable, as indicated by the green fluorescence. It was also possible to 
observe the movement of BLBs within yeast cells, as shown by time-lapse photography in Figure 4 .
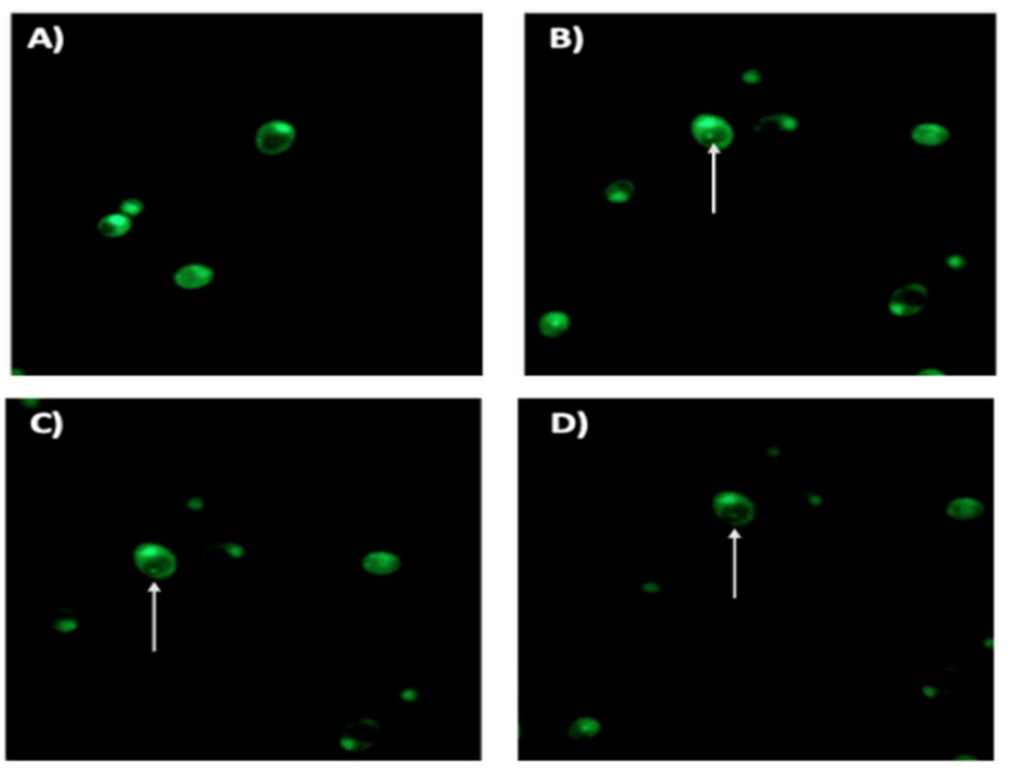

Figure 4. Fluorescence microscopy of a $48 \mathrm{~h}$ H. pylori J99-C. albicans ATCC 10231 co-culture in the presence of 1/4 MIC AMX showing yeast cells containing BLBs, putatively H. pylori. (A) shows a pure culture of C. albicans 10231 (negative control) while (B-D) show micrographs of a viable BLB (arrow) within a viable yeast cell taken at $1 \mathrm{~s}$ intervals. AMX: amoxicillin, BLBs: bacteria-like body.

\subsection{Detection of H. pylori Genes in Total DNA Extracted from C. albicans Cells}

The presence of intrayeast $H$. pylori was confirmed, amplifying, by PCR, the $16 \mathrm{~S}$ rDNA gene of $H$. pylori in total C. albicans DNA of yeast cells previously co-cultured with the bacterium in the presence of antibiotic (1/4 MIC AMX or 1/4 MIC CLT). After agarose gel electrophoresis, the presence of an amplicon having the expected size in all samples of yeasts co-cultured with the bacterium and in the positive control (pure H. pylori) was revealed. The amplicon was not detected in the negative control (pure C. albicans) (Figure 5).
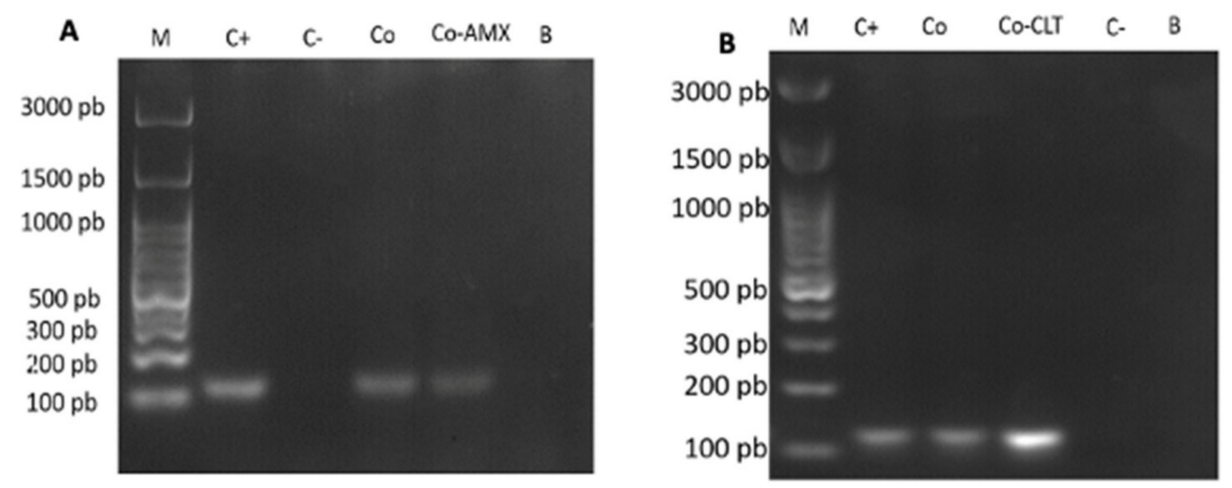

Figure 5. Images from $2 \%$ agarose gel electrophoresis showing the amplicons obtained after PCR amplification of the 16S rDNA gene of H. pylori in total C. albicans DNA after incubating an $H$. pylori J99-C. albicans ATCC 10231 co-culture during $48 \mathrm{~h}$ in the presence of AMX (A) or CLT (B) and then incubating on chloramphenicol supplemented Sabouraud agar to eliminate extracellular bacteria. Expected size for the amplicon:110 bp. M: molecular weight marker; $\mathrm{C}+$ : positive control (pure H. pylori); C-: negative control (pure C. albicans), Co: co-culture without the antibiotic; Co-AMX or Co-CLT: co-culture in the presence of 1/4 MIC AMX (A) or 1/4 MIC CLT (B); B: blank (PCR grade water). AMX: amoxicillin, CLT: clarithromycin. 


\section{Discussion}

In order to obtain co-cultures containing the higher possible number of viable cells of both microorganisms, the first task was to determine the growth curves for each one of them. The growth curve obtained in this work for H. pylori $\mathrm{J} 99$ strain was similar to that reported for the same strain by Baltrus and Guillemin [27] cultured under similar conditions. Other strains of this species also showed a similar growth when cultured in other culture media [28-30]. The growth of C. albicans ATCC 10231 in BB-FCS was not different from that reported when cultured in yeast extract peptone-dextrose (YPD) broth or Sabouraud broth, even at different temperatures [31-33].

The second task was to determine the MIC of AMX and CLT for both microorganisms, in order to know what concentration was stressful but not inhibitory for H. pylori; in addition, to know whether the antibiotics used had any effect on the growth of the yeast. The MIC of both antibiotics for H. pylori was $0.03 \mu \mathrm{g} \mathrm{mL}^{-1}$. Therefore, in accordance with the reference values reported by EUCAST [34], the H. pylori J99 strain was sensitive to AMX (resistant $>0.125 \mu \mathrm{g} \mathrm{mL}^{-1}$ ) and also to CLT (resistant $>0.5 \mu \mathrm{g} \mathrm{mL}^{-1}$ ). In our internalization assays, we used a sub-MIC concentration, specifically $0.0075 \mu \mathrm{g} \mathrm{mL}^{-1}$, equivalent to $1 / 4$ MIC. This concentration was chosen because studies reported for $H$. pylori using different antibiotics have used this same fraction of the MIC [35,36].

It has been postulated that the internalization of bacteria within eukaryotic microorganisms could represent a mechanism to persist under unfavorable conditions $[24,37,38]$. Therefore, the harboring of $H$. pylori within nearly $30 \%$ of C. albicans cells after $48 \mathrm{~h}$ of co-culture in the absence of antibiotics can be attributed to the basal stress caused by factors such as the transfer from solid media to broth, extended periods of incubation and the accumulation of metabolites. In the present work, other factors, such as deprivation of nutrients and $\mathrm{pH}$ changes, extensively discussed in [39,40], were kept under control. To the above-mentioned factors, the additional stress caused by the presence of antibiotic at $1 / 4$ MIC concentration was added as a possible triggering factor for the internalization of $H$. pylori within C. albicans. Results showed that, when compared to the control, AMX caused a significant increase in the internalization of this bacterium into yeast cells, while CLT did not. These results suggest that CLT does not fulfill the necessary requirements to trigger the harboring of $H$. pylori within $C$. albicans cells. Studies on the individual effect of antibiotics, such as AMX or CLT, on H. pylori have reported that they have similar effects on the morphological changes, biofilm formation and genetic modifications in this species [41,42]. Nevertheless, the significantly different percentage of $H$. pylori harboring yeasts suggests that the mechanism of action of the antibiotic may be playing an important role in the pressure exerted on $H$. pylori to trigger its internalization.

AMX is a $\beta$-lactam antibiotic that irreversibly binds to penicillin-binding proteins (PBP), having a preference for PBP2, interrupting the synthesis of peptidoglycan [43]. PBP2 is a D,D-transpeptidase closely associated with bacterial morphology, mainly to the lateral peptidoglycan synthesis, which generates the bacillar morphology. Therefore, the impairment of the function of PBP2 brings, consequently, the generation of the coccoid morphology in bacteria such as H. pylori and E. coli [18,44-46]. Thus, AMX, having a direct effect on the stability of the structure of $H$. pylori, becomes a source of stress, which could lead to H. pylori generating more quickly survival strategies, such as entering into yeast cells to protect itself from the effect of AMX. These considerations may justify the higher percentage of $H$. pylori-bearing yeasts in the co-cultures where this antibiotic (AMX) was used as a stressor.

On the contrary, CLT, being a member of the macrolide family of antibiotics, reversibly binds to $23 \mathrm{~S}$ rRNA of the $50 \mathrm{~S}$ subunit of the ribosome, the region neighboring the peptidyl transferase, an enzyme catalyzing the binding of the peptide during elongation. Hence, the binding of CLT interrupts protein synthesis [47]; therefore, it affects the viability of bacteria. Sub-inhibitory CLT concentrations cause several effects in other bacterial species, such as a decreased adherence of Staphylococcus aureus to cells of the oral mucosa [48]. On Pseudomonas aeruginosa, sub-inhibitory CLT concentrations cause a low rate of synthesis 
of various virulence factors, such as elastase, DNase, proteases and lecithinase, resulting in a decreased motility, suppression of twitching and inhibition of the biofilm matrix and proteases synthesis by bacteria [49-51]. In H. pylori, sub-inhibitory concentrations of CLT have been shown to cause the shift from the helical to the coccoid morphology and to increase biofilm formation $[41,52,53]$ mechanisms used by $H$. pylori to protect itself from environmental stress, contributing to the fact that the entry of yeasts is not the only protection mechanism that this pathogen has to avoid the damage generated by the presence of CLT. This would support the results obtained in this work, where it was observed that $1 / 4$ MIC of CLT did not show any effect on the entry of bacteria into C. albicans when compared with the results obtained for AMX and the control. This may be explained by the reversibility of the action mechanism of this antibiotic at $1 / 4$ MIC concentration, minimizing the antibiotic pressure as a source of stress promoting the entry of H. pylori into eukaryotic cells. CLT pressure could be greater if the concentration of the antibiotic is increased. In fact, higher concentrations of CLT cause an increase in coccoid structures as a response to stress [52].

It is noteworthy that this study showed that H. pylori also enters into the yeast cells in the absence of an apparent stressing factor but that the number of yeast cells harboring BLBs increased in the presence of AMX. On the other hand, the cell viability assay (Figure 4) shows that $H$. pylori remains viable within the yeast because, as mentioned in Materials and Methods, yeasts harboring BLBs were reseeded six times in Sabouraud agar medium containing chloramphenicol antibiotic before the assay to evaluate viability. This assay was complemented with the amplification of the H. pylori $r R N A 16 S$ gene from the total DNA extracted from C. albicans cells in which BLBs were observed (Figure 5).

It has been proposed that the presence of bacteria within eukaryotic microorganisms is a strategy to persist in the environment and even a strategy for dissemination $[22,37,54-56]$. The present study provides the first evidence of the in vitro entry of $H$. pylori cells into $C$. albicans cells promoted by the presence of antibiotics, mainly AMX, used for the treatment of this bacterium. This finding may reveal a protecting mechanism of $H$. pylori to cope with the presence of antibiotics used to treat it, making it difficult the eradicate it in clinical practice. It becomes necessary to pursue, in this line of research, the consequences of the harboring of $\mathrm{H}$. pylori within eukaryotic cells and to improve our knowledge regarding the factors favoring this symbiosis.

\section{Materials and Methods}

\subsection{Strains and Culture Conditions}

The strains used in this study included H. pylori ATCC 700824, also regularly known as J99 straina denomination also used in this manuscript, and C. albicans ATCC 10231. Both strains are maintained at the culture collection of the Laboratory of Bacterial Pathogenicity, Department of Microbiology, University of Concepcion, Concepcion, Chile. All the procedures described below were carried out aseptically.

H. pylori was cultured on plates containing Columbia agar (OXOID, Basingstoke, United Kingdom) supplemented with $5 \%$ horse blood Plates were incubated at $37^{\circ} \mathrm{C}$ for $36 \mathrm{~h}$ under microaerobic conditions ( $10 \% \mathrm{CO}_{2}$ and $5 \%$ oxygen) in a 3429-model incubator (Thermo Scientific, Waltham, MA, USA). C. albicans was cultured on plates containing Sabouraud dextrose agar (Merck, Darmstadt, Germany) supplemented with chloramphenicol, following the instructions of the manufacturer (OXOID, Basingstoke, United Kingdom). Incubation was carried out at $37^{\circ} \mathrm{C}$ during $24 \mathrm{~h}$ under aerobic conditions in a ZDP-2160 model incubator (ZHICHENG, Shanghai, China). The purity of $H$. pylori cultures was verified by Gram staining and urease production using the rapid urease test. The rapid urease test was done by obtaining an inoculum, with a cotton swab, from Columbia agar (OXOID, Basingstoke, UK) cultures and transferring it to $0.5 \mathrm{~mL}$ Eppendorf tubes containing $0.4 \mathrm{~mL}$ Urea agar base (OXOID, Basingstoke, United Kingdom). In the case of C. albicans, its characteristic morphology was verified in wet mounts, and its purity was verified by Gram staining. 


\subsection{Growth Curves of H. pylori $J 99$ and C. albicans ATCC 10231 Strains}

This assay was done to identify the timespan required to obtain H. pylori and C. albicans growing in their exponential phase in order to obtain the largest number of cells possible of each microorganism.

From a $36 \mathrm{~h}$ culture of $H$. pylori, whose morphology was verified after Gram staining, as described above, an initial inoculum containing $1.5 \times 10^{6}$ colony forming units $(\mathrm{CFU}) \mathrm{mL}^{-1}$ in $5 \mathrm{~mL}$ of Brucella broth (BB) (Difco, Wokingham, UK) supplemented with $10 \%$ fetal calf serum (Becton Dickinson, East Rutherford, NJ, USA) (BB-FCS) was prepared in $16 \times 100 \mathrm{~mm}$ glass tubes (Pyrex, Swedesboro, NJ, USA). Cultures were incubated for $60 \mathrm{~h}$ at $37^{\circ} \mathrm{C}$ under microaerobic conditions using a 3429 model incubator (Thermo Scientific, Waltham, MA, USA). Aliquots of $200 \mu \mathrm{L}$ were obtained at $12 \mathrm{~h}$ intervals and transferred to wells of a 96 wells microplate, (TR5003 model, Thomas Scientific, Swedesboro, NJ, USA), and the turbidity was measured using an Infinite M200 PRO model spectrophotometer (TECAN, Männedorf, Switzerland) at $600 \mathrm{~nm}$.

From a $24 \mathrm{~h}$ culture of $C$. albicans, an inoculum containing $1.5 \times 10^{6} \mathrm{CFU} \mathrm{mL}^{-1}$ in $5 \mathrm{~mL}$ of BB-FCS was prepared and incubated at $37^{\circ} \mathrm{C}$ during $12 \mathrm{~h}$ under aerobic conditions. Then, $200 \mu \mathrm{L}$ of this suspension were incubated in a 96-well microplate (TR5003 model, Thomas Scientific, Swedesboro, NJ, USA), and the growth was evaluated measuring the absorbance at $600 \mathrm{~nm}$ every $4 \mathrm{~h}$ during $48 \mathrm{~h}$ using a model Infinite M200 PRO spectrophotometer (TECAN, Männedorf, Switzerland) following the procedure described by Maidan et al. [31]. In addition, the growth and cell morphology of yeasts were monitored by optical microscopy.

\subsection{Preparation of Antibiotics Stock Solutions}

Stock solutions of AMX and CLT (both obtained from Sigma Aldrich, St. Louis, MO, USA) were prepared in $1 \mathrm{M}$ ammonia (Santa Cruz, Dallas, TX, USA) or M dimethyl sulfoxide (DMSO) (Sigma-Aldrich, St. Louis, MO, USA), respectively. Stock solutions were filtered using $0.22 \mu \mathrm{m}$ pore size sterile filters (Thermo Scientific, Waltham, MA, USA) and then aliquoted at final concentrations of $0.24,0.12,0.06,0.03$ and $0.015 \mu \mathrm{g} \mathrm{mL}^{-1}$.

\subsection{Determination of the MIC of Amoxicillin and Clarithromycin for H. pylori J99}

The CLSI agar dilution technique methodology [26] was used to determine the MIC of both antibiotics for H. pylori 999 using 6-well microplates (TR5003 model, Thomas Scientific, Swedesboro, NJ, USA) containing Müller Hinton (MH) agar (Difco, Wokingham, United Kingdom) supplemented with 7\% horse serum (Biological Industries, Cromwell, CT, USA) plus the different antibiotics concentrations. A McFarland 2 initial inoculum was prepared from a H. pylori J99 strain cultured on Columbia agar for $72 \mathrm{~h}$, and $3 \mu \mathrm{L}$ of this inoculum were seeded in each well and incubated for $48 \mathrm{~h}$. MIC was determined as the antibiotic concentration at which no bacterial growth was observed.

\subsection{Determination of H. pylori 999 Internalization into C. albicans ATCC 10231 Cells in the Presence of Amoxicillin or Clarithromycin}

The subinhibitory concentration of AMX or CLT used in this assay was $1 / 4$ of the MIC determined by the previous experiment. From cultures of H. pylori J99 and C. albicans ATCC 10231 grown in plates until exponential phase (20 and $10 \mathrm{~h}$, respectively), suspensions were independently prepared in $5 \mathrm{~mL}$ of BB-FCS. Then, the $5 \mathrm{~mL}$ of $C$. albicans suspension was added to the $H$. pylori suspension totaling $10 \mathrm{~mL}$, and a final concentration of $3 \times 10^{8} \mathrm{CFU} \mathrm{mL} \mathrm{mL}^{-1}$ comparing the turbidity of the suspension with a MacFarland scale. Before incubating, either of the antibiotics (AMX or CLT) was added to reach a concentration equal to $1 / 4$ MIC. Then, cultures were incubated (Thermo Scientific, Waltham, MA, USA) at $37^{\circ} \mathrm{C}$ under microaerobic condition, $10 \% \mathrm{CO}_{2}$, and $20 \mu \mathrm{L}$ of the co-culture was collected at times $0,1,3,6,12,24$ or $48 \mathrm{~h}$. At each of these times, a sample was placed on a slide, covered with a coverslip and observed under an optical microscope (Leica, Wetzlar, Germany) using the 100X objective lens to determine the number of yeast cells containing BLBs. The per- 
centage of yeast cells containing BLBs was calculated after counting yeast cells containing BLBs or not containing them in 100 microscope fields for each time sampled. A similar co-culture but lacking antibiotics was used as control. This assay-including co-cultures plus AMX, co-cultures plus CLT and control co-cultures without antibiotics-was done in duplicate.

Then, the percentages of yeast cells containing BLBs in the presence or absence of antibiotics were incorporated into an Excel Microsoft 16.40 database (Microsoft, Redmond, WA, USA) and processed using the SPSS 23.0 software (IBM Company, Armonk, NY, USA). The levels of the categorical variables were expressed by incubation time and their percentages of BLBs containing yeasts, being the relationship between the categorical variables determined using the Student's $t$-test. Values of $p<0.05$ were considered significant.

The following assays were required to obtain yeast cells from the co-cultures free of extracellular $H$. pylori cells. For this purpose, inocula were obtained from the $48 \mathrm{~h}$ co-cultures described above using cotton swabs (QIAGEN, Hilden, Germany) and seeded on the surface of plates containing Sabouraud agar (Merck, Darmstadt, Germany) supplemented with chloramphenicol, following the instructions of the manufacturer (OXOID, Basingstoke, UK). Plates were incubated at $37^{\circ} \mathrm{C}$ forz $48 \mathrm{~h}$ under aerobic conditions. After incubation, Gram stainings were prepared to confirm the absence of extracellular bacteria to continue with the following experiments (i.e., the cell viability assay and the extraction of DNA from yeasts).

\subsection{Cell Viability Assay}

From the co-cultures showing the presence of yeasts harboring BLBs, $1 \mathrm{~mL}$ suspensions with a turbidity of $0.5 \mathrm{McF}$ arland were prepared in sterile saline solution and $1 \mu \mathrm{L}$ of the working solution of the LIVE/DEAD BacLight Bacterial Viability kit L-7012 (Thermo Scientific, Waltham, MA, USA) was added. After $15 \mathrm{~min}$ of incubation at room temperature in the darkness, suspensions were gently vortexed for $3 \mathrm{~s}$. Then, $10 \mu \mathrm{L}$ of each suspension was placed on a slide to be observed using the 100X objective lens of a fluorescence microscope equipped with an integrated camera (Motic, Viking Way, Richmond, VA, Canada). Filters used to evaluate cell viability were FITC (AT480/535) and TRITC (AT540/605) to observe the green fluorescence of SYTO 9 fluorochrome and the red fluorescence of propidium iodide, respectively. Images were processed using the ImageJ software (NIH Image, Bethesda, MD, USA) to merge the images obtained.

\subsection{Detection of H. pylori Genes in Total DNA Extracted from C. albicans Cells}

To avoid the contamination of yeast cells DNA with DNA from extracellular H. pylori cells, C. albicans cells previously co-cultured with the pathogenic bacterium having BLBs were seeded on Sabouraud agar supplemented with chloramphenicol and reseeded six times in this same medium to eliminate extracellular $H$. pylori cells from the cultures, a condition confirmed by Gram staining.

\subsection{Extraction and Quantification of DNA from Yeasts}

DNA was extracted from yeasts previously co-incubated with $H$. pylori cells and then incubated in chloramphenicol-supplemented Sabouraud agar (Merck, Darmstadt, Germany) to obtain yeast cells free of extracellular H. pylori. DNA was also extracted from pure cultures of $H$. pylori $\mathrm{J} 99$ (positive control) and C. albicans ATCC 10231 (negative control). In all cases, DNA was extracted using the UltraClean Microbial DNA Isolation kit (MO BIO, QIAGEN, Hilden, Germany) following the instructions of the manufacturer. To quantify the extracted DNA, $2 \mu \mathrm{L}$ of each sample were placed in independent wells of a NanoQuant plate (TECAN, Männedorf, Switzerland), and the absorbance was measured at 260 and $280 \mathrm{~nm}$ using an Infinite M200Pro model spectrophotometer (TECAN, Männedorf, Switzerland). Samples having a 260/280 absorbance ratio between 1.8 and 2.0 were selected. These samples were kept at $-20^{\circ} \mathrm{C}$ until further use. Table 1 shows the quantification and 
purity of the DNA extracted from yeasts obtained from co-cultures in the presence of AMX or CLT and from the control cultured in the absence of antibiotics.

Table 1. Quantification and purity of DNA extracted from $48 \mathrm{~h} \mathrm{H}$. pylori J99-C. albicans ATCC 90028 co-cultures in the presence of AMX or CLT antibiotics and from a control without antibiotic.

\begin{tabular}{cccc}
\hline Sample & Media & DE & \\
\hline Control & 35.4 & 3.39 & $\mathrm{~B}$ \\
AMX & 46.85 & 2.19 & $\mathrm{~A}$ \\
CLT & 31.15 & 1.59 & $\mathrm{~B}$ \\
\hline
\end{tabular}

AMX: amoxicillin, CLT: clarithromycin. According to the Tukey statistical test, mains sharing the same letter are not significantly different $(p>0.05)$.

\subsection{Amplification of the $16 S$ rDNA Gene of H. pylori $J 99$}

The amplification of a $110 \mathrm{bp}$ fragment of the $16 \mathrm{~S}$ rDNA gene of H. pylori J99 was done by PCR using the SapphireAmp Fast PCR Master Mix kit (TAKARA BIO INC, Shiga, Japan). For this purpose, $12.5 \mu \mathrm{L}$ master mix, $1 \mu \mathrm{L}$ forward primer (Table 2), $1 \mu \mathrm{L}$ reverse primer (Table 2), $2 \mu \mathrm{L}$ of sample or control DNA and $8.5 \mu \mathrm{L}$ PCR grade $\mathrm{H}_{2} \mathrm{O}$ were used, totaling $25 \mu \mathrm{L}$ of PCR mixture. PCR conditions were: initial denaturation at $94{ }^{\circ} \mathrm{C}$ for $1 \mathrm{~min}$, denaturation at $98^{\circ} \mathrm{C}$ for $5 \mathrm{~s}$, hybridization at $53^{\circ} \mathrm{C}$ for $5 \mathrm{~s}$ and extension at $72{ }^{\circ} \mathrm{C}$ for $40 \mathrm{~s}$. All samples were subjected to 30 PCR cycles using a thermocycler (Fermelo Biotec T 960, Providencia, Santiago, Chile).

Table 2. Primers used for the amplification of H. pylori J99 strain $16 S$ rRNA.

\begin{tabular}{ccccc}
\hline Gene & Sequence & Tm $\left({ }^{\circ} \mathbf{C}\right)$ & bp (Amplicon) & Reference \\
\hline \multirow{2}{*}{165 rDNA } & $\begin{array}{c}\text { F-5'CTCGAGAGACTAAGCCCTCC3 } \\
\text { R-5'ATTACTGACGCTGATGTGC3 }\end{array}$ & 53 & 110 & {$[19,26,57-60]$} \\
\hline
\end{tabular}

\subsection{Agarose gel Electrophoresis}

After amplifying the $110 \mathrm{bp}$ fragment of $H$. pylori $\mathrm{J} 9916 \mathrm{~S}$ rDNA gene, samples were subsequently analyzed by $2 \%$ agarose gel electrophoresis. Agarose ( $0.6 \mathrm{~g})$ (Lonza, Walkersville, MD, USA) was dissolved in $30 \mathrm{~mL}$ of $1 \mathrm{X}$ TAE (Thermo Scientific, Waltham, MA, USA), and then $0.6 \mu \mathrm{L}$ GelRed (Biotium, Landing Parkway, Fremont, CA, USA) were added. Ten microliter of the products of amplification and $1 \mu \mathrm{L}$ of molecular weight marker (100 bp marker (MAESTROGEN, Hsinchu, Taiwan)) were loaded in the gels. Electrophoresis was run for $90 \mathrm{~min}$ at $70 \mathrm{~V}$. Bands were observed and recorded under an Enduro model transilluminator (Labnet, Edison, NJ, USA)

\section{Conclusions}

The internalization of $H$. pylori to C. albicans in an environment in the presence of an antibiotic is dependent on the type of antibiotic used, suggesting that a therapy that includes amoxicillin could stimulate the entry of the bacterium to Candida, thus adversely affecting the success of treatment.

Supplementary Materials: The following are available online at https:/ / www.mdpi.com/2076-0 817/10/3/382/s1, Video S1: optical microscopy of wet mounts of a 24 h H. pylori J99-C. albicans ATCC10231 co-culture in the presence of a subinhibitory concentration of AMX.

Author Contributions: Conceptualization, L.B., K.S.-A., A.G.-C.; methodology, L.B., K.S.-A., C.P.-S., A.G.-C.; validation, L.B., K.S.-A., C.P.-S., H.B., C.T.S., A.G.-C.; formal analysis, K.S.-A.; investigation, L.B., K.S.-A., C.P.-S., A.G.-C.; resources, H.B., A.G.-C.; data curation, L.B., K.S.-A., V.L.C., K.S.; writing-original draft preparation, K.S.-A., C.P.-S., H.B., A.G.-C.; writing-review and editing, L.B., K.S.-A.; C.P.-S., H.B., V.L.C., A.G.-C.; visualization, K.S.-A., C.P.-S., H.B., V.L.C., K.S.; supervision, A.G.-C.; project administration, A.G.-C.; funding acquisition, A.G.-C. All authors have read and agreed to the published version of the manuscript. 
Funding: This work was supported by Grant VRID-Enlace 218.036.047-1.0, Universidad de Concepcion, Concepcion, Chile.

Institutional Review Board Statement: Not applicable.

Informed Consent Statement: Not applicable.

Data Availability Statement: No comments.

Acknowledgments: The authors acknowledge the collaboration and support of Laboratorio Pasteur.

Conflicts of Interest: There is no conflict of interests.

\section{References}

1. Abadi, A.T.B.; Ierardi, E. Vonoprazan and Helicobacter pylori Treatment: A Lesson from Japan or a Limited Geographic Phenomenon? Front. Pharm. 2019, 10, 316. [CrossRef]

2. IARC Working Group on the Evaluation of Carcinogenic Risks to Humans. Schistosomes, Liver Flukes and Helicobacter pylori. IARC Working Group on the Evaluation of Carcinogenic Risks to Humans; International Agency for Research on Cancer: Lyon, France, 1994.

3. Hooi, J.K.Y.; Lai, W.Y.; Ng, W.K.; Suen, M.M.Y.; Underwood, F.E.; Tanyingoh, D.; Malfertheiner, P.; Graham, D.Y.; Wong, V.W.S.; Wu, J.C.Y.; et al. Global Prevalence of Helicobacter pylori Infection: Systematic Review and Meta-Analysis. Gastroenterology 2017, 153, 420-429. [CrossRef] [PubMed]

4. Amieva, M.; Peek, R.M. Pathobiology of Helicobacter pylori-Induced Gastric Cancer. Gastroenterology 2016, 150, 64-78. [CrossRef] [PubMed]

5. Burucoa, C.; Axon, A. Epidemiology of Helicobacter pylori Infection. Helicobacter 2017, 22 (Suppl. 1). [CrossRef]

6. Fischbach, W.; Malfertheiner, P. Helicobacter pylori Infection. Dtsch. Arztebl. Int. 2018, 115, 429-436. [CrossRef] [PubMed]

7. Wang, Y.-H.; Lv, Z.-F.; Zhong, Y.; Liu, D.-S.; Chen, S.-P.; Xie, Y. The Internalization of Helicobacter pylori Plays a Role in the Failure of H. pylori Eradication. Helicobacter 2017, 22. [CrossRef]

8. Calvet, X. Dealing with Uncertainty in the Treatment of Helicobacter pylori. Adv. Chronic Dis. 2018, 9, 93-102. [CrossRef] [PubMed]

9. Fallone, C.A.; Moss, S.F.; Malfertheiner, P. Reconciliation of Recent Helicobacter pylori Treatment Guidelines in a Time of Increasing Resistance to Antibiotics. Gastroenterology 2019, 157, 44-53. [CrossRef] [PubMed]

10. Goderska, K.; Agudo Pena, S.; Alarcon, T. Helicobacter pylori Treatment: Antibiotics or Probiotics. Appl. Microbiol. Biotechnol. 2018, 102,1-7. [CrossRef]

11. Hu, Y.; Zhu, Y.; Lu, N.-H. Recent Progress in Helicobacter pylori Treatment. Chin. Med. J. Engl. 2020, 133, 335-343. [CrossRef] [PubMed]

12. O'Connor, A.; Liou, J.-M.; Gisbert, J.P.; O'Morain, C. Review: Treatment of Helicobacter pylori Infection 2019. Helicobacter 2019, 24 (Suppl. 1), e12640. [CrossRef] [PubMed]

13. Savoldi, A.; Carrara, E.; Graham, D.Y.; Conti, M.; Tacconelli, E. Prevalence of Antibiotic Resistance in Helicobacter pylori: A Systematic Review and Meta-Analysis in World Health Organization Regions. Gastroenterology 2018, 155, 1372-1382.e17. [CrossRef]

14. Parra-Sepúlveda, C.; Merino, J.S.; Sáez-Carrillo, K.; González, C.; García-Cancino, A. Antibiotic Resistance Surveillance of Helicobacter pylori at the Biobío Region (Chile) in a Decade. Arq. Gastroenterol. 2019, 56, 361-366. [CrossRef] [PubMed]

15. Tacconelli, E.; Carrara, E.; Savoldi, A.; Harbarth, S.; Mendelson, M.; Monnet, D.L.; Pulcini, C.; Kahlmeter, G.; Kluytmans, J.; Carmeli, Y.; et al. Discovery, Research, and Development of New Antibiotics: The WHO Priority List of Antibiotic-Resistant Bacteria and Tuberculosis. Lancet Infect. Dis. 2018, 18, 318-327. [CrossRef]

16. Kadkhodaei, S.; Siavoshi, F.; Noghabi, K. Mucoid and Coccoid Helicobacter pylori with Fast Growth and Antibiotic Resistance. Helicobacter 2019, 25. [CrossRef] [PubMed]

17. Reshetnyak, V.I.; Reshetnyak, T.M. Significance of Dormant Forms of Helicobacter pylori in Ulcerogenesis. World J. Gastroenterol. 2017, 23, 4867-4878. [CrossRef]

18. Krzyżek, P.; Grande, R. Transformation of Helicobacter pylori into Coccoid Forms as a Challenge for Research Determining Activity of Antimicrobial Substances. Pathogens 2020, 9, 184. [CrossRef] [PubMed]

19. Matamala-Valdés, L.; Sánchez-Alonzo, K.; Parra, C.; Sáez, K.; Aguayo-Reyes, A.; García, A. Detection of Intracellular Helicobacter pylori in Candida. SPP from Neonate Oral Swabs. Rev. Assoc. Med. Bras. 2018, 64, 928-935. [CrossRef]

20. Saniee, P.; Siavoshi, F.; Nikbakht Broujeni, G.; Khormali, M.; Sarrafnejad, A.; Malekzadeh, R. Localization of H. pylori within the Vacuole of Candida Yeast by Direct Immunofluorescence Technique. Arch. Iran Med. 2013, 16, 705-710.

21. Saniee, P.; Siavoshi, F.; Nikbakht Broujeni, G.; Khormali, M.; Sarrafnejad, A.; Malekzadeh, R. Immunodetection of Helicobacter pylori-Specific Proteins in Oral and Gastric Candida Yeasts. Arch. Iran Med. 2013, 16, 624-630.

22. Siavoshi, F.; Taghikhani, A.; Malekzadeh, R.; Sarrafnejad, A.; Kashanian, M.; Jamal, A.S.; Saniee, P.; Sadeghi, S.; Sharifi, A.H. The Role of Mother's Oral and Vaginal Yeasts in Transmission of Helicobacter pylori to Neonates. Arch. Iran Med. 2013, 16, 288-294. [PubMed]

23. Lai, C.-H.; Kuo, C.-H.; Chen, P.-Y.; Poon, S.-K.; Chang, C.-S.; Wang, W.-C. Association of Antibiotic Resistance and Higher Internalization Activity in Resistant Helicobacter pylori Isolates. J. Antimicrob. Chemother. 2006, 57, 466-471. [CrossRef] [PubMed] 
24. Sánchez-Alonzo, K.; Parra-Sepúlveda, C.; Vega, S.; Bernasconi, H.; Campos, V.L.; Smith, C.T.; Sáez, K.; García-Cancino, A. In Vitro Incorporation of Helicobacter pylori into Candida albicans Caused by Acidic PH Stress. Pathogens 2020, 9, 489. [CrossRef]

25. Angebault, C.; Djossou, F.; Abélanet, S.; Permal, E.; Ben Soltana, M.; Diancourt, L.; Bouchier, C.; Woerther, P.-L.; Catzeflis, F.; Andremont, A.; et al. Candida albicans Is Not Always the Preferential Yeast Colonizing Humans: A Study in Wayampi Amerindians. J. Infect. Dis. 2013, 208, 1705-1716. [CrossRef] [PubMed]

26. Moris, D.V.; Melhem, M.S.C.; Martins, M.A.; Mendes, R.P. Oral Candida Spp. Colonization in Human Immunodeficiency Virus-Infected Individuals. J. Venom. Anim. Toxins Incl. Trop. Dis. 2008, 14, 224-257. [CrossRef]

27. Baltrus, D.A.; Guillemin, K. Multiple Phases of Competence Occur during the Helicobacter pylori Growth Cycle. Fems Microbiol. Lett. 2006, 255, 148-155. [CrossRef] [PubMed]

28. Bury-Moné, S.; Kaakoush, N.O.; Asencio, C.; Mégraud, F.; Thibonnier, M.; De Reuse, H.; Mendz, G.L. Is Helicobacter pylori a True Microaerophile? Helicobacter 2006, 11, 296-303. [CrossRef]

29. Parreira, P.; Magalhães, A.; Gonçalves, I.C.; Gomes, J.; Vidal, R.; Reis, C.A.; Leckband, D.E.; Martins, M.C.L. Effect of Surface Chemistry on Bacterial Adhesion, Viability, and Morphology. J. Biomed. Mater. Res. Part A 2011, 99, 344-353. [CrossRef]

30. Estibariz, I.; Overmann, A.; Ailloud, F.; Krebes, J.; Josenhans, C.; Suerbaum, S. The Core Genome M5C Methyltransferase JHP1050 (M.Hpy99III) Plays an Important Role in Orchestrating Gene Expression in Helicobacter pylori. Nucleic Acids Res. 2019, 47, 2336-2348. [CrossRef] [PubMed]

31. Maidan, M.M.; De Rop, L.; Relloso, M.; Diez-Orejas, R.; Thevelein, J.M.; Van Dijck, P. Combined Inactivation of the Candida albicans GPR1 and TPS2 Genes Results in Avirulence in a Mouse Model for Systemic Infection. Infect. Immun. 2008, 76, 1686-1694. [CrossRef]

32. Thewes, S.; Moran, G.P.; Magee, B.B.; Schaller, M.; Sullivan, D.J.; Hube, B. Phenotypic Screening, Transcriptional Profiling, and Comparative Genomic Analysis of an Invasive and Non-Invasive Strain of Candida albicans. BMC Microbiol. 2008, 8, 187. [CrossRef]

33. Weerasekera, M.M.; Wijesinghe, G.K.; Jayarathna, T.A.; Gunasekara, C.P.; Fernando, N.; Kottegoda, N.; Samaranayake, L.P. Culture Media Profoundly Affect Candida albicans and Candida tropicalis Growth, Adhesion and Biofilm Development. Mem. Inst. Oswaldo Cruz. 2016, 111, 697-702. [CrossRef] [PubMed]

34. EUCAST: Clinical Breakpoints and Dosing of Antibiotics. Available online: https://www.eucast.org/clinical_breakpoints/ (accessed on 24 December 2020).

35. Donofrio, F.C.; Miranda, E.T.; Maia, D.C.G.; Carlos, I.Z.; Raddi, M.S.G. Subinhibitory Concentrations of Amoxicillin on Helicobacter pylori Increase Apoptosis in RAW 264.7 Cells. J. Chem. Pharm. Res. 2015, 7, 178-181.

36. Momynaliev, K.; Chelysheva, V.; Selezneva, O.; Larin, A.; Akopian, T.; Alexeev, D.; Le Berre, V.; Sokol, S.; Francois, J.-M.; Govorun, V. Modulation of Helicobacter pylori Transcriptional Profile by Subinhibitory Concentrations of Rifampicin. Biotechnol. Theory Pract. 2013, 23-29. [CrossRef]

37. Siavoshi, F.; Sahraee, M.; Ebrahimi, H.; Sarrafnejad, A.; Saniee, P. Natural Fruits, Flowers, Honey, and Honeybees Harbor Helicobacter pylori-Positive Yeasts. Helicobacter 2018, 23, e12471. [CrossRef] [PubMed]

38. Siavoshi, F.; Saniee, P. Vacuoles of Candida Yeast as a Specialized Niche for Helicobacter pylori. World J. Gastroenterol. 2014, 20, 5263-5273. [CrossRef] [PubMed]

39. Berry, V.; Jennings, K.; Woodnutt, G. Bactericidal and Morphological Effects of Amoxicillin on Helicobacter pylori. Antimicrob. Agents Chemother. 1995, 39, 1859-1861. [CrossRef]

40. Shahamat, M.; Mai, U.E.; Paszko-Kolva, C.; Yamamoto, H.; Colwell, R.R. Evaluation of Liquid Media for Growth of Helicobacter pylori. J. Clin. Microbiol. 1991, 29, 2835-2837. [CrossRef] [PubMed]

41. Attaran, B.; Falsafi, T.; Ghorbanmehr, N. Effect of Biofilm Formation by Clinical Isolates of Helicobacter pylori on the EffluxMediated Resistance to Commonly Used Antibiotics. World J. Gastroenterol. 2017, 23, 1163-1170. [CrossRef]

42. Yonezawa, H.; Osaki, T.; Hanawa, T.; Kurata, S.; Ochiai, K.; Kamiya, S. Impact of Helicobacter pylori Biofilm Formation on Clarithromycin Susceptibility and Generation of Resistance Mutations. PLoS ONE 2013, 8, e0073301. [CrossRef] [PubMed]

43. Francesco, V.D.; Zullo, A.; Hassan, C.; Giorgio, F.; Rosania, R.; Ierardi, E. Mechanisms of Helicobacter pylori Antibiotic Resistance: An Updated Appraisal. World J. Gastrointest. Pathophysiol. 2011, 2, 35-41. [CrossRef]

44. Sauvage, E.; Kerff, F.; Terrak, M.; Ayala, J.A.; Charlier, P. The Penicillin-Binding Proteins: Structure and Role in Peptidoglycan Biosynthesis. FEMS Microbiol. Rev. 2008, 32, 234-258. [CrossRef] [PubMed]

45. Bush, K. Antimicrobial Agents Targeting Bacterial Cell Walls and Cell Membranes. Rev. Sci. Tech. 2012, 31, 43-56. [CrossRef]

46. Chaput, C.; Ecobichon, C.; Cayet, N.; Girardin, S.E.; Werts, C.; Guadagnini, S.; Prévost, M.-C.; Mengin-Lecreulx, D.; Labigne, A.; Boneca, I.G. Role of AmiA in the Morphological Transition of Helicobacter pylori and in Immune Escape. PLoS Pathog. 2006,2 , e97. [CrossRef]

47. Lambert, T. Antibiotics That Affect the Ribosome. Rev. Sci. Tech. 2012, 31, 57-64. [CrossRef]

48. Braga, P.C. Effects of Subinhibitory Concentrations of Seven Macrolides and Four Fluoroquinolones on Adhesion of Staphylococcus aureus to Human Mucosal Cells. Chemotherapy 1994, 40, 304-310. [CrossRef] [PubMed]

49. Shryock, T.R.; Mortensen, J.E.; Baumholtz, M. The Effects of Macrolides on the Expression of Bacterial Virulence Mechanisms. J. Antimicrob. Chemother. 1998, 41, 505-512. [CrossRef] [PubMed]

50. Wozniak, D.J.; Keyser, R. Effects of Subinhibitory Concentrations of Macrolide Antibiotics on Pseudomonas Aeruginosa. Chest 2004, 125, 62S-69S. [CrossRef] 
51. Garey, K.; Vo, Q.; Lewis, R.; Saengcharoen, W.; LaRocco, M.; Tam, V. Increased Bacterial Adherence and Biomass in Pseudomonas aeruginosa Bacteria Exposed to Clarithromycin. Diagn. Microbiol. Infect. Dis. 2008, 63, 81-86. [CrossRef]

52. Faghri, J.; Poursina, F.; Moghim, S.; Zarkesh Esfahani, H.; Nasr Esfahani, B.; Fazeli, H.; Mirzaei, N.; Jamshidian, A.; Ghasemian Safaei, H. Morphological and Bactericidal Effects of Different Antibiotics on Helicobacter Pylori. Jundishapur J. Microbiol. $2014,7$. [CrossRef] [PubMed]

53. Bessa, L.J.; Grande, R.; Iorio, D.D.; Giulio, M.D.; Campli, E.D.; Cellini, L. Helicobacter Pylori Free-Living and Biofilm Modes of Growth: Behavior in Response to Different Culture Media. APMIS 2013, 121, 549-560. [CrossRef] [PubMed]

54. Moreno-Mesonero, L.; Moreno, Y.; Alonso, J.L.; Ferrús, M.A. DVC-FISH and PMA-QPCR Techniques to Assess the Survival of Helicobacter pylori inside Acanthamoeba castellanii. Res. Microbiol. 2016, 167, 29-34. [CrossRef]

55. Salmanian, A.-H.; Siavoshi, F.; Beyrami, Z.; Latifi-Navid, S.; Tavakolian, A.; Sadjadi, A. Foodborne Yeasts Serve as Reservoirs of Helicobacter pylori. J. Food Saf. 2012, 32, 152-160. [CrossRef]

56. Siavoshi, F.; Salmanian, A.H.; Akbari, F.; Kbari, F.A.; Malekzadeh, R.; Massarrat, S. Detection of Helicobacter pylori-Specific Genes in the Oral Yeast. Helicobacter 2005, 10, 318-322. [CrossRef]

57. Paredes-Osses, E.; Sáez, K.; Sanhueza, E.; Hebel, S.; González, C.; Briceño, C.; García Cancino, A. Association between CagA, VacAi, and DupA Genes of Helicobacter pylori and Gastroduodenal Pathologies in Chilean Patients. Folia Microbiol. Praha 2017, 62, 437-444. [CrossRef] [PubMed]

58. Nakajima, N.; Kuwayama, H.; Ito, Y.; Iwasaki, A.; Arakawa, Y. Gastric Epithelial Cells Stimulate Helicobacter pylori Growth. J. Clin. Gastroenterol. 1998, 27 (Suppl. 1), S138-S140. [CrossRef] [PubMed]

59. Premoli, G.; González, A.; Millán-Mendoza, B.; Percoco, T.; Vielma, A. Diagnóstico de Helicobacter pylori Mediante La Reacción En Cadena de La Polimerasa. Rev. Cuba. Med. Trop. 2004, 56, 85-90.

60. Sánchez-Alonzo, K.; Parra-Sepúlveda, C.; Vergara, L.; Bernasconi, H.; García-Cancino, A.; Sánchez-Alonzo, K.; Parra-Sepúlveda, C.; Vergara, L.; Bernasconi, H.; García-Cancino, A. Detection of Helicobacter pylori in Oral Yeasts from Students of a Chilean University. Rev. Assoc. Med. Bras. 2020, 66, 1509-1514. [CrossRef] [PubMed] 